\title{
The role of net ecosystem productivity and of inventories in climate change research: the need for "net ecosystem productivity with harvest", NEPH
}

\author{
E. D. Schulze ${ }^{1 *}$ (D, R. Valentini ${ }^{2}$ and O. Bouriaud ${ }^{3}$
}

\begin{abstract}
Background: There is an urgent need for quantifying the terrestrial carbon sink in the context of global carbon emissions. However, neither the flux measurements, nor the national wood balances fulfil this purpose. In this discussion article we point at various shortcomings and necessary improvements of these approaches in order to achieve a true quantification of the carbon exchange of land surfaces.

Results: We discuss the necessity of incorporating all lateral fluxes, but mainly the export of biomass by harvest, into the flux balance and to recognize feedbacks between management and fluxes to make flux measurements compatible with inventories. At the same time, we discuss the necessity that national reports of wood use need to fully recognize the use of wood for energy use. Both approaches of establishing an ecosystem carbon balance, fluxes and inventories, have shortcomings.

Conclusions: Including harvest and feedbacks by management appears to be the main requirement for the flux approach. A better quantification of wood use for bioenergy seems a real need for integrating the national wood balances into the global carbon cycle.
\end{abstract}

Keywords: Terrestrial carbon sink, Flux measurements, Carbon inventories, National wood balances

\section{Background}

The measurements of Net Ecosystem Exchange, NEE, as instantaneous measurement of fluxes, and of Net Ecosystem Productivity, NEP, as a measure for an ecosystem flux balance, have been a success story (Valentini 2003; Baldocchi 2014, 2020). For the first time, it was possible to measure the net flux of $\mathrm{CO}_{2}$ for plant communities at a geographic scale of about $1 \mathrm{~km}^{2}$ and a time scale between seconds and years. The measurement of eddy fluxes is continuous, with minimal interference of instrumentation to natural processes unlike e.g. cuvettes or chambers. It was initially hoped that this methodology (Aubinet et al. 2012), together with other measurements,

\footnotetext{
* Correspondence: dschulze@bgc-jena.mpg.de

${ }^{1}$ Max Planck Institute for Biogeochemistry, Box 100164, Jena, Germany

Full list of author information is available at the end of the article
}

such as the national wood balances, would help to quantify carbon uptake and storage changes of ecosystems in a way that would comply to the requirements of the Climate Convention and its Climate Protocols (Martin et al. 1998). In addition, because of the high time resolution, the methodology of eddy flux measurements is compatible to weather measurements. Therefore, it became possible to relate ecosystem processes directly to a fluctuating environment (Baldocchi et al. 2018). Thus, the flux measurements became a standard methodology to translate climate change to land surface processes (Baldocchi 2020).

In terms of quantifying ecosystem storage, however, the flux methodology was not able to compete with standardized inventory-based assessments of carbon pools (Grassi et al. 2018), mainly because of 
geomorphological limitations (slopes) and of the representation of landscapes, which are of a larger scale than a flux footprint, but also because the flux balance ignores lateral fluxes (i.e. fluxes corresponding to losses that are not related to respiration) that are quantified by inventories (Gielen et al. 2011; Kirschbaum et al. 2019). Thus, repeated measurements of carbon stocks (gridbased inventories) remain the basis to obtain fluxes at landscape scale (e.g. Campioli et al. 2016), even though measurements of stocks also have limitations: the observations are not continuous, at best yearly, and the consistency of the sampling design is crucial for the validity of the estimations. Forest inventories focus on aboveground biomass of trees and neglect belowground stores. This lack of an ecosystem dimension has in part been supplemented by grid-based soil inventories.

Here we investigate how the two approaches relate to each other, and what would be needed to bridge the flux approach with the inventory approach. In this context the international agreements aim at repeated assessments of carbon stores in 5-year steps (Paris agreement: UNFCCC-COP21 2015). Considering this time scale, the instantaneous fluxes are mainly of scientific interest and a basis for modeling exercises. We hypothesize that the flux approach should include lateral fluxes, mainly harvest, in order to become compatible with the inventory approach and to quantify feedbacks between harvest and growth. In this communication we are not able to comprehensively address climate mitigation and refer to Schulze et al. (2020).

\section{Methods}

This study is based on reviewing published literature on this topic.

\section{Results and discussion}

\section{The net ecosystem balance}

The terminology of the ecosystem greenhouse gas balance was defined in the context of the European Project CarboEurope (Fig. 1a, Schulze et al. 2009) showing the diversity in the way basic fluxes are accounted for and their consequences on the resulting balance terms.

Photosynthesis, the only process that immobilizes atmospheric $\mathrm{CO}_{2}$ into organic material, is approximated from eddy flux measurements as NEE plus (total) ecosystem respiration under vertical flux conditions. This modelled quantity is called Gross Primary Production, GPP. An uncertainty remains between GPP and photosynthesis, and about feedbacks between lateral fluxes and ecosystem respiration (Gielen et al. 2011). Photosynthesis delivers non-structural carbohydrates that are used to support the maintenance of existing biomass, and to allow for growth (Schulze et al. 2000). The carbon needed for maintenance and growth emerges as autotrophic respiration $\left(R_{\mathrm{a}}\right)$, where the term "autotrophic" indicates that this respiration originates from the vegetation and includes both aerial and belowground respiration. GPP minus autotrophic respiration results in a quantification of plant growth, termed as Net Primary Production, NPP, which includes above and below-ground growth, and it includes carbon that is transported to the mycorrhiza, and that is lost by exudates and by above- and below-ground herbivory (Jarvis and Linder 2007). Thus, NPP is also a theoretical quantity that cannot be fully quantified in the field. The CarboEurope scheme (Fig. 1) takes additional lateral fluxes into account. These are mainly the harvest, resulting in Net Biome Productivity, $\mathrm{NBP}_{\text {biomass. }}$ With agriculture, manure is added stimulating plant growth by added nutrients (Marschner 1995), and NBP would include the carbon added by manure (but would not recognize added nitrogen in mineral fertilizer). Harvest and manure have feedbacks on respiration of heterotrophic organisms $\left(R_{\mathrm{h}}\right)$. The same is true for fires, where $\mathrm{C}$ is lost to the atmosphere, bypassing $R_{\mathrm{a}}$. The carbon loss by fire is not a lateral flux in the strict sense, but a carbon loss that is not related to respiration, and it remains unmeasured. The losses by fire can only be modelled (Law et al. 2004). Generally, not all of the woody biomass burns to ash and harvest could also take charred trees. The same is true for wind-throw where thrown trees are harvested under managed conditions. Less clear is the feedback on ecosystem respiration by transport of DOC/DIC (Camino-Serrano et al. 2018), of lateral transport of carbon by water (Cole et al. 2007) and other greenhouse gas losses (e.g. Methane). Considering all these inputs and losses results in Net Biome Productivity, NBP, at a time scale that is generally longer than that of flux measurements, depending on the type of land use. Harvest may occur in forests at decadal scale, but it is annual in crops, monthly in meadows, and continuous in rangelands. Depending on site conditions and the type of management, the ecosystem produces additional greenhouse gases, other than $\mathrm{CO}_{2}$. These are incorporated into this scheme as $\mathrm{CO}_{2 \text { equivalent }}$ fluxes. All fluxes sum up as Net Greenhouse Gas Balance, NGB.

Dolman (2019) pointed out that a flux balance suffers additionally from time lags. The non-structural carbohydrates in trees are on average 10 years old, and this is the source for autotrophic respiration of tree stems (e.g. Carbone et al. 2013; Trumbore et al. 2015). The age of $\mathrm{CO}_{2}$ in heterotrophic respiration is on average about 20 years (Schulze et al. 2020). Thus $R_{\mathrm{a}}$ and $R_{\mathrm{h}}$ hinge behind GPP by about 20 years and adding $R_{\mathrm{h}}$ to NEE to derive GPP is assuming steady state conditions. However, with climate change, increasing atmospheric $\mathrm{CO}_{2}$ concentrations and atmospheric deposition, this assumption apparently does not hold. Likewise, management 


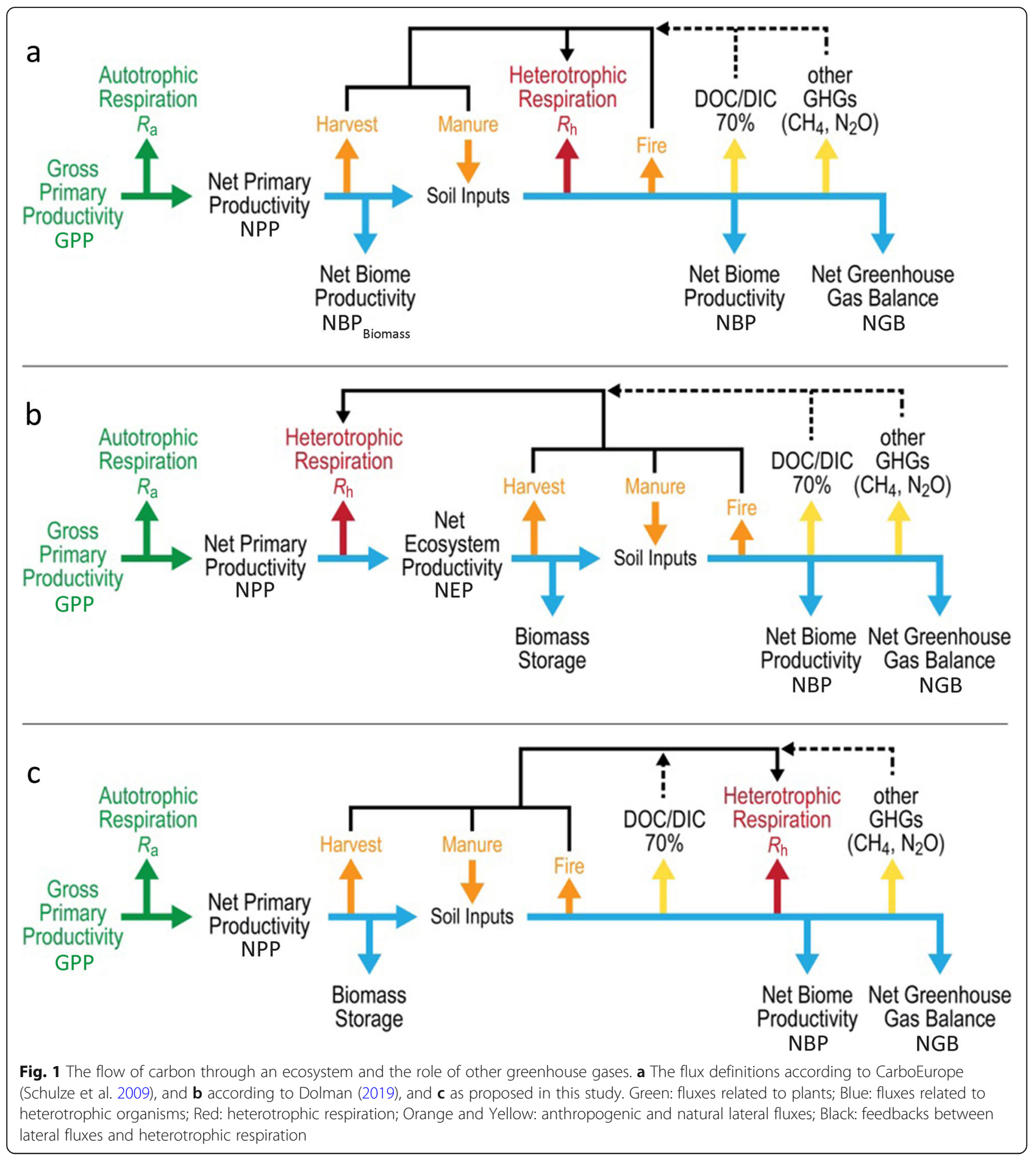

interventions contribute to changes of the fluxes with potentially long-lasting positive or negative effects and feedbacks (Noormets et al. 2015) globally stimulating $R_{\mathrm{h}}$, decreasing $R_{\mathrm{a}}$ being rather neutral for NPP, but decrease GPP. Thus, even with taking numerous flux stations as a basis, inversion modeling would not be able to quantify harvesting. Only repeated inventories would integrate these time lags and detect exports. However, they largely ignore below-ground processes and assumptions need to be made in order to represent variations in belowground storage. Overall, it becomes obvious that the time dimension has been ignored in flux measurements, and it emerges that carbon sequestration is only a way to "buy time" not to solve the problem (Valentini 2003). 
Maybe there is a threshold when the sink as measured by eddy covariance is not anymore a sink due to the legacy of the past.

Even though the basic definitions are known since long (Schulze et al. 2000), it remains an open discussion, whether heterotrophic respiration should be subtracted from NPP before (Fig. 1b) or after (Fig. 1a) consideration of the lateral fluxes. Great efforts were undertaken for quantifying atmospheric lateral fluxes from flux divergence (Foken 2017), but removals by disturbances and management have not been accounted for, although they may be larger in magnitude and feedback on $R_{\mathrm{h}}$. Dolman (2019) considered the lateral fluxes after calculation of NEP (Fig. 1b). This, however, neglects feedbacks of lateral fluxes on NEP. Harvest reportedly has a moderate but positive feedback on GPP, probably due to higher light use efficiency and reduced water interception, and on $R_{\mathrm{a}}$ through the reduction of the living biomass. The observation by Anthoni et al. (2004), Vesala et al. (2005) and Granier et al. (2008) that removal of biomass from a forest stand had no effect on NEE suggests, that GPP and respiration responded positively to this management treatment. Thus, a low level of harvest has a positive effect on growth of remaining trees because competition between trees is relaxed. NEE represents the ecosystem flux, and thus inherently it should include all feedbacks from associated lateral fluxes, but, the interpretation of such measurement remains weak, if lateral fluxes are ignored. Thus, feedbacks remain unrecognized and are associated with other factors. Because of their effects on multiple processes and feedbacks on other fluxes, human-driven fluxes cannot be strictly distinguished.

Both schemes (Figs. 1a and b) are not fully consistent, because fire and DOC losses are considered after subtraction of $R_{\mathrm{h}}$, even though fire can have a profound effect on $R_{\mathrm{h}}$. Thus, to be totally consistent, $R_{\mathrm{h}}$ should be considered after all lateral fluxes have been taken into account (Fig. 1c). It also remains an open discussion, if the fluxes of other greenhouse-gases $\left(\mathrm{CH}_{4}, \mathrm{~N}_{2} \mathrm{O}\right)$ should be included in NEP given their high radiative forcing.

It is interesting to note that NEP, defined as GPP $-R_{\mathrm{a}}$ - $R_{\mathrm{h}}$ (Dolman 2019), and not as GPP $-R_{\mathrm{a}}$ - harvest + manure $-R_{\mathrm{h}}$, does not show a timing component in Fig. $1 \mathrm{a}$ and $\mathrm{c}$. Following the seminal publication of Körner (2003) who characterized ecosystems as "slow in, fast out" systems where carbon stock may build up over decades and are lost by disturbance or harvest within days. This difference in time scales was not bridged in the flux schemes. Considering disturbances and associated lateral fluxes could change the apparent "sink" of flux measurements into a "source" (Schulze et al. 2010). The apparently ever-lasting sink, as measured by NEE, is misleading, because the estimated stored carbon does not remain in the ecosystem, but it is carried out as harvest in most managed ecosystems. Some of the lateral fluxes may even have additional effects, such as the deployment of manure, where is not the added carbon, but the added nutrients -mainly nitrogen- that affect all fluxes. Similar nutritional effects exist with other disturbances, such as fire, and of $\mathrm{N}$ inputs from air pollution. In the case of harvested wood, carbon is respired or emitted geographically elsewhere. Since $\mathrm{CO}_{2}$ emissions from products are part of the global natural carbon cycle, the global carbon balance could be misinterpreted, if NEE does not respond to lateral fluxes, even though, there is the chance of double counting of $\mathrm{CO}_{2}$ at global scale.

We are aware that when considering the importance of lateral fluxes, NEP contributes little to understanding the global carbon balance because it does not include the carbon-emissions that are geographically displaced. Sure enough NBP would be the advanced parameter, but a linear flux scheme of carbon decay (Schulze et al. 2000), does not account for feedbacks on ecosystem fluxes. To make this clear we might start with different land uses.

In agriculture, "dead" material of grain and straw is removed after harvest, which should lower heterotrophic respiration as compared to a situation where grain and straw remain on site. The carbon in grain and straw is respired geographically elsewhere, maybe on a different continent. Thus the net flux balance should be NEE = GPP $-R_{\mathrm{a}}-R_{\mathrm{h} \text { onsite }}-R_{\mathrm{h} \text { harvest }}$. There is little feedback on GPP but a feedback on $R_{\mathrm{h}}$ should exist, but manure and mineral fertilizer should ideally compensate the effects of biomass removal. Double counting of carbon would be possible, because emissions from harvested biomass would also be measured at the consumer level.

In grasslands, $\mathrm{NEE}=\mathrm{GPP}-R_{\mathrm{a}}-R_{\mathrm{h} \text { onsite }}-R_{\mathrm{h} \text { grazers }}$. In this case, the removal of green biomass has profound positive feedback on GPP that could balance the export. For rangelands, respiration of grazing animals would be included, but in case of hay-meadows $R_{\mathrm{h}}$ of domestic animals would not be included. Again, double counting of $\mathrm{C}$ would be possible at global scale.

In forests, NEE $=\mathrm{GPP}-R_{\mathrm{a}}-R_{\mathrm{h}}-$ Carbon $_{\text {in }}$ stand growth. Forests are complicated due to the fact that most of the harvested wood is physiologically dead material that was photosynthetically assimilated decades ago. The physiologically active component of wood is the sapwood that results from a balance of growth and formation of dead hardwood (Thurner et al. 2019). In addition, trees would be lost by self-thinning of up-growing stands (Luyssaert et al. 2011). Thus changes in stand wood biomass and not tree growth would be the appropriate parameter. "Stand wood biomass increment" would be potentially the amount of wood that can be harvested and exported under sustainable management, or it 
would remain on site under protected conditions. In the case of protection, the accumulated dead wood would contribute to $R_{\mathrm{h}}$ at a later point of time. The removal of wood has profound feedback on $R_{\mathrm{a}}$ and thus on GPP and on $R_{\mathrm{h}}$ feeding back on NEE. For understanding these feedbacks, the incorporation of "stand wood biomass increment" into NEE would be desirable. Again double counting of emitted carbon would be possible.

We suggest to make this variable distinct from NEP and NBP. We suggest to introduce a new variable $\mathrm{NEPH}$, which would be Net Ecosystem Productivity with harvest. NEPH would be different from NBP, because the focus is on harvest due to its global importance.

Our suggested change in the calculation of NEE would make ecosystem services visible (Fig. 2), and it would make a management of the feedbacks possible. On the other hand, a global disadvantage would emerge that emissions are associated with the producer of biomass without any regulation of consumption at the biomassuser side. We want to understand the feedbacks of harvest on ecosystem fluxes as well as the consumption at the same time. Thus, we may have to live with double counting at global scale. This would not be harmful, and could be corrected, if it remains visible and known.

Given the range of flux definitions, IPCC took a different venture. The IPCC guidelines (2006) consider carbon stocks only, and calculate net fluxes from repeated measurements of stocks. This can be done across large landscapes, but it would require harmonization of stock sampling methods (Barreiro et al. 2016), a challenge that national forest inventories are currently lacking (Tomppo and Schadauer 2012). Nevertheless, the temporal resolution of stock surveys is at best annual, and generally based on 5- to 10-year cycles for large-scale inventories, with a modest capacity to quantify consequences of particular or episodic events (storm/fire).

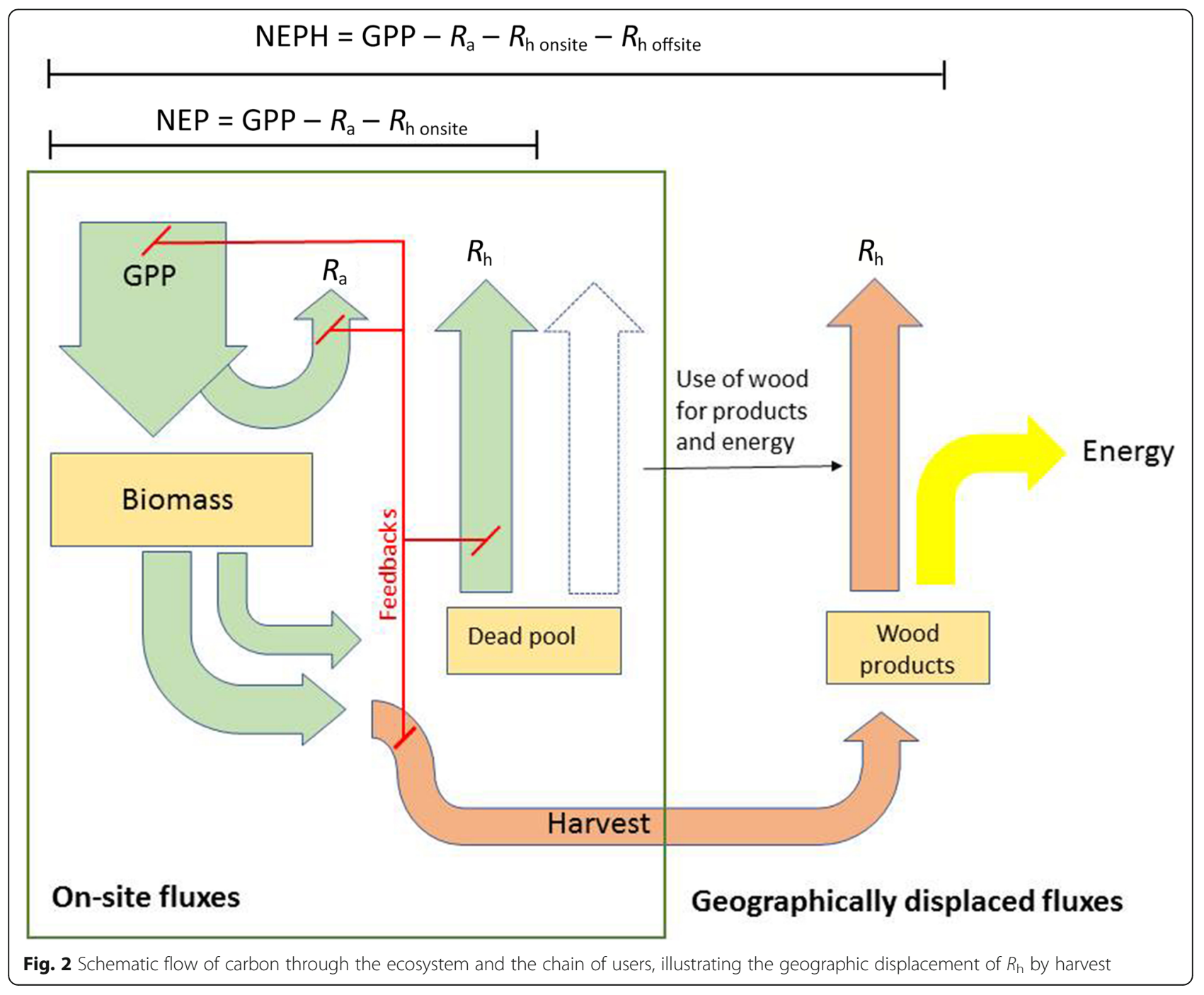




\section{The global carbon balance}

The global terrestrial sinks and sources of greenhousegases need to be quantified in the context of a global flux balance, including all fluxes because the international agreements consider not just $\mathrm{CO}_{2}$ but a GHGbalance. Thus, it is NGB and not NEP nor NBP that is desired. Based on NGB, CarboEurope summarized that forests and grasslands balance emissions from agriculture (Schulze et al. 2009). Thus $\mathrm{NGB}_{\text {Europe }}$ is close to zero, i.e. the land surface is about neutral. However, changes by management are possible with Land-Use Change (LUC) in direction of a larger sink by more forests and by changes in Land Use (LU) in direction of lesser emissions of other greenhouse gases from grassland and agriculture.

Politically a sustainable management of the land surface is wanted on a long-time scale. In this case, harvest would balance biomass increment as a measure of growth, and under ideal conditions stocks should remain about constant at landscape scale (von Carlowitz 1732; Schulze et al. 2020). Increasing or decreasing stocks (e.g. in forests) would not be captured by NEP unless feedback effects were be captured, which has not been supported by data. Indeed, cuttings do not necessarily result in sizable changes in fluxes despite their impact on the stocks (Granier et al. 2008; Wilkinson et al. 2016). Since heart wood of living trees is mainly dead material, fluxes are not related to stocks.

At larger scale, European forests showed a sensible increase of their stocks during the last 50 years (Ciais et al. 2008) along with positive trends in their increment (Pretzsch et al. 2014) despite intense use of wood resources. This increase of stocks was mainly due to a regulation of the age class structure, but also a response to atmospheric nitrogen deposition. Therefore, this increase in stocks is only temporary and large mortalities are already being reported in Europe, due to repetitive drought stress (DeSoto et al. 2020). Given the expected increase in disturbance rates (Millar and Stephenson 2015), increasing stocks seems unlikely in the long-term and a potentially dangerous management scheme where stand collapse could happen more frequently and at large scales. The effects of these stock changes on NEE remain unclear.

In addition, at the Durban Conference of the Parties (UNFCCC-COP17 2011), it was decided that products should be included in the stock-taking process. Thus, carbon pools outside the ecosystem become important. Schulze et al. (2020) pointed out that this extension is not sufficient to understanding the role of forests in climate mitigation. Indeed, products are transient pools and must be followed to their end of use, where about $50 \%$ of the carbon in products is decomposed by microorganisms and $50 \%$ is used for energy production, replacing fossil fuel. In short, wood used for material and construction largely ends up combusted, and the dominant contribution to mitigation remains the energyand product-substitution which directly result in reduced fossil fuel consumption, but this is not accounted for in the forest sector. Rather, total harvest is accounted for as immediate combustion. Thus, the global carbon cycle must be extended up to the point where the $\mathrm{CO}_{2}$ fixed by GPP is released again as $\mathrm{CO}_{2}$ to the atmosphere by decomposition or by burning.

The new EU-Legislation (2018) has taken the processes up to the use of products into account.

\section{A seminal example: the German wood balance}

There are major gaps of information along all accounting schemes, which result in unintended wishes and false interpretations. We like to demonstrate the accounting problems taking the German forest carbon balance as example which shows that estimating even large fluxes from the wood compartment such as harvest remain challenging. In Germany, the aboveground wood growth, which is a sub-quantity of biomass growth (wood growth $=$ NPP minus litter) has been quantified by repeated grid-based inventories across the country to be $120 \pm 0.4$ million $\mathrm{m}^{3}$ per year (BWI-3 2012). The harvest, as accounted for by the statistical bureau based on wood sales, sums up to only 56 million $\mathrm{m}^{3}$ per year. The reported harvest increased in recent years, but a full balance will only available with the new National Forest Inventory in 2021. Thus there is a gap of about 60 million $\mathrm{m}^{3}$ per year compared to growth, and 20 million $\mathrm{m}^{3}$ per year deficit to timber harvest as measured by the inventory (estimated to be 117 million $\mathrm{m}^{3}$ per year $( \pm 2.8 \%$ sampling error), BMEL 2014). This gap was used as argument, that not all wood is needed, and that without harm a major proportion of land can be put under nature protection (BMU 2008). However, it was shown by Schulze et al. (2020) that this gap does not exist, because bark and oversize tree parts are unaccounted removals. In addition, small land holders use their forest only for harvesting domestic fuel without entering into a commercial wood market. Taking all these un-recorded fluxes into account the total fellings were estimated to be 86 million $\mathrm{m}^{3} \cdot \mathrm{yr}^{-1}$. But even this number may be an underestimate. Friderichs (2020) estimates that total fellings in Germany are as high as 99 million $\mathrm{m}^{3} \cdot \mathrm{yr}^{-1}$. This is close to the measured growth rate. Additional nature conservation activities would be balanced by imports from other regions of the globe enlarging the ecological footprint (Schulze et al. 2016). This, however, is not captured by NEP and a fraction of harvest below the prescribed diameter threshold likewise escapes the inventory-based estimations. 


\section{Conclusions}

Eddy covariance methods deliver high frequency measures of land-atmospheric exchange fluxes. Its contribution to the understanding of ecophysiological and meteorological drivers of the carbon balance is tremendous. The integration of these measures provides estimates of productivity and respiratory losses, but not of storage and not of harvest. When they occur, lateral fluxes escape the flux monitoring with potentially detrimental effects on the ecosystem balance considered. The different time constant for fluxes and management actions depends on the type of land-use, and range between decades for forests to continuous losses with grazing. In addition, the return fluxes through respiration and through combustion of wood products are acting on a much longer time scale than photosynthesis. Hence, producing annual carbon balance estimates is more a conceptual exercise than a reality in forests, and both flux-based or inventory-based approaches require complements and modeling to deliver estimations.

At this point NEE and NEP are quantities that helps understanding interactions with climate, but do not support the global needs for establishing a carbon balance.

Lateral fluxes, dominantly harvest, need to be accounted for in the carbon budget. However, estimates of harvest prove difficult and they are probably consistently underestimated, regardless of the method. Furthermore, extending the carbon flow to wood products only partly solves the problem since wood products represent a transient pool. Long-lasting forms of retention are useful in buying time, and have a particular social and cultural value, but after use, about 50\% of the wood products and about $30 \%$ of wood growth are used to produce energy, which otherwise would have been produced by fossil fuels energy. This ultimate use returns photosynthetic $\mathrm{C}$ back to the atmosphere as $\mathrm{CO}_{2}$ at a time-frame similar to decomposition which would otherwise release the same carbon to the atmosphere. Based on these considerations we conclude:

- NEP is a quantity that helps to understanding interactions with climate, but it does not support the global needs for establishing a carbon balance.

- NEP alone, without considering lateral fluxes at ecosystem level, is not an adequate basis for assessing the carbon balance of ecosystems.

- Since the national wood balances are incomplete, a flux-based C balance (flux + export) would be a great progress even at the geographic scale of flux measurements.

\section{Acknowledgements}

We acknowledge the help of Annett Boerner (www.dn.com.au/annettboerner.html) for help with art work.

\section{Authors' contributions}

EDS has prepared the first draft of this paper; OB has revised and edited the paper; RV made key suggestions for improving the paper. All authors have participated in the preparation of this study. The author(s) read and approved the final manuscript.

\section{Availability of data and materials}

No specific new data are used.

Ethics approval and consent to participate

Not applicable.

\section{Competing interests}

There are no competing interests. The study is non-commercial.

\section{Author details}

${ }^{1}$ Max Planck Institute for Biogeochemistry, Box 100164, Jena, Germany. ${ }^{2}$ Department of Forest Environment and Resources, University of Tuscia, 01100 Viterbo, Italy. 'Laboratoire d'Inventaire Forestier, IGN, Nancy, France.

Received: 13 October 2020 Accepted: 12 February 2021

Published online: 01 March 2021

\section{References}

Anthoni PM, Knohl A, Rebmann C, Freibauer A, Mund M, Ziegler W, Kolle O, Schulze ED (2004) Forest and agricultural land-use-dependent $\mathrm{CO}_{2}$ exchange in Thuringia, Germany. Glob Chang Biol 10(12):2005-2019

Aubinet M, Vesala T, Papale D (2012) Eddy covariance: a practical guide to measurement and data analysis. Springer, Berlin ISBN 978-94-007-2351-1

Baldocchi D (2014) Measuring fluxes of trace gases and energy between ecosystems and the atmosphere - the state and future of the eddy covariance method. Glob Chang Biol 20:3600-3609

Baldocchi D, Chu H, Reichstein M (2018) Inter-annual variability of net and gross ecosystem carbon fluxes: a review. Agric For Meteorol 249:520-533

Baldocchi DD (2020) How eddy covariance flux measurements have contributed to our understanding of global change biology. Glob Chang Biol 26:242-260

Barreiro S, Scheelhaas M-J, Kändler G, Antón-Fernández C, Colin A, Bontemps J-D, Alberdi I, Condés S, Dumitru M, Ferezliev A, Fischer C, Gasparini P, Gschwantner T, Kindermann G, Kjartansson B, Kovácsevics P, Kucera M, Lundström A, Marin G, Mozgeris G, Nord-Larsen T, Packalen T, Redmond J, Sacchelli S, Sims A, Snorrason A, Stoyanov N, Thürig E, Wikberg P-E (2016) Overview of methods and tools for evaluating future woody biomass availability in European countries. Ann For Sci 73:823-837

BMEL (2014) Der Wald in Deutschland: Ausgewählte Ergebnisse der dritten Bundeswaldinventur. Bundesministerium für Ernährung und Landwirtschaft, Berlin, p 50

BMU (2008) Nationale Strategie zur biologischen Vielfalt. BMUB, Berlin, p 178

BWI-3 (2012) Third national forest inventory. https://bwi.info. Accessed $15 \mathrm{Sep}$ 2020

Camino-Serrano M, Guenet B, Luyssaert S, Ciais P, Bastrikov V, De Vos B, Gielen B, Gleixner G, Jornet-Puig A, Kaiser K, Kothawala D, Lauerwald R, Peñuelas J, Schrumpf M, Vicca S, Vuichard N, Walmsley D, Janssens IA (2018) ORCHIDEESOM: modeling soil organic carbon (SOC) and dissolved organic carbon (DOC) dynamics along vertical soil profiles in Europe. Geosci Model Dev 11: 937-957

Campioli M, Malhi Y, Vicca S, Luyssaert S, Papale D, Peñuelas J, Reichstein M, Migliavacca M, Arain MA, Janssens IA (2016) Evaluating the convergence between eddy-covariance and biometric methods for assessing carbon budgets of forests. Nat Commun 7:13717

Carbone MS, Czimczik Cl, Keenan TF, Murakami PF, Pederson N, Schaberg PG, Xu X, Richardson AD (2013) Age, allocation and availability of nonstructural carbon in mature red maple trees. New Phytol 200:1145-1155

Ciais P, Schelhaas MJ, Zaehle S, Pião SL, Cescatti A, Liski J, Luyssaert S, Le-Maire G, Schulze ED, Bouriaud O, Freibauer A, Valentini R, Nabuurs GJ (2008) Carbon accumulation in European forests. Nat Geosci 1:425-429

Cole JJ, Prairie YT, Caraco NF, McDowell WH, Tranvik LJ, Striegl RG, Duarte CM, Kortelainen P, Downing JA, Middelburg JJ, Melack J (2007) Plumbing the global carbon cycle: integrating inland waters into the terrestrial carbon budget. Ecosystems 10:172-185

DeSoto L, Cailleret M, Sterck F, Jansen S, Kramer K, Robert EMR, Aakala T, Amoroso MM, Bigler C, Camarero JJ, Čufar K, Gea-Izquierdo G, Gillner S, 
Haavik L, Hereş A-M, Kane JM, Kharuk VI, Kitzberger T, Klein T, Levanič T, Linares JC, Mäkinen H, Oberhuber W, Papadopoulos A, Rohner B, SangüesaBarreda G, Stojanovic DB, Suárez ML, Villalba R, Martínez-Vilalta J (2020) Low growth resilience to drought is related to future mortality risk in trees. Nat Commun 11(1):545

Dolman H (2019) Biogeochemical cycles and climate. Oxford University Press, Oxford, p 251

EU-legislation (2018) Verordnung (EU) 2018/841 des Europäischen Parlaments und des Rates vom 30. Mai 2018 über die Einbeziehung der Emissionen und des Abbaus von Treibhausgasen aus Landnutzung.

Landnutzungsänderungen und Forstwirtschaft in den Rahmen für die Klimaund Energiepolitik bis 2030 und zur Änderung der Verordnung (EU) Nr 525/ 2013 und des Beschlusses Nr 529/2013/EU. Amtsblatt der Europäischen Union L156/1 bis 25

Foken T (2017) Energy and matter fluxes of a spruce forest ecosystem. Springer, Heidelberg, p 532 Ecological studies, vol 229

Friderichs R (2020) Auf verlorenem Posten? Das neue Waldsterben aus forstwirtschaftlicher Praxis. Die Politische Meinung:44-48

Gielen B, Neirynck J, Luyssaert S, Janssens IA (2011) The importance of dissolved organic carbon fluxes for the carbon balance of a temperate scots pine forest. Agric For Meteorol 151(3):270-278

Granier A, Bréda N, Longdoz B, Gross P, Ngao J (2008) Ten years of fluxes and stand growth in a young beech forest at Hesse, North-Eastern France. Ann For Sci 65:704-726

Grassi G, Pilli R, House J, Federici S, Kurz WA (2018) Science-based approach for credible accounting of mitigation in managed forests. Carbon Bal Manage $13: 8$

IPCC Guidelines (2006) IPCC guidelines for national greenhouse gas inventories. https://www.ipcc-nggip.iges.or.jp/public/2006gl/vol4.html. Accessed 15 Sep 2020

Jarvis PG, Linder S (2007) Forests remove carbon dioxide from the atmosphere: spruce forest tales. In: Freer-Smith PH, Broadmeadow MSJ, Lynch JM (eds) Forestry and climate change. CAB International, Wallingford, pp 60-72

Kirschbaum MU, Zeng G, Ximenes F, Giltrap DL, Zeldis JR (2019) Towards a more complete quantification of the global carbon cycle. Biogeosciences 16(3): $831-846$

Körner C (2003) Slow in, rapid out - carbon flux studies and Kyoto targets. Science 300:1242-1243

Law BE, Turner D, Campbell J, Sun OJ, Van Tuyl S, Ritts WD, Cohen WB (2004) Disturbance and climate effects on carbon stocks and fluxes across Western Oregon USA. Glob Chang Biol 10:1429-1444

Luyssaert S, Hessenmöller D, von Lüpke N, Kaiser S, Schulze ED (2011) Quantifying land-use and disturbance intensity in forestry, based on the selfthinning relationship. Ecol Appl 21:3272-3284. https://doi.org/10.1890/10-23 95.1

Marschner H (1995) Mineral nutrition of higher plants. Academic Press, London, $\mathrm{p}$ 889

Martin PH, Valentini R, Jaques M, Fabbri K, Galati D, Quarantino R, Moncrieff JB, Jarvis PG, Jensen NO, Lindroth A, Grelle A, Aubinet M, Ceulemans R, Kowalski AS, Vesala T, Keronen P, Matteucci G, Granier A, Berbigier P, Loustau D, Schulze ED, Tenhunen J, Rebmann C, Dolman AJ, Elbers JE, Bernhofer C, Grunwald T, Thorgeirsson H, Kennedy P, Folving S (1998) New estimate of the carbon sink strength of EU forests integrating flux measurements, field surveys and space observations: 0.17-0.35 Gt(C). Ambio 27(7):582-584

Millar Cl, Stephenson NL (2015) Temperate forest health in an era of emerging megadisturbance. Science 349(6250):823-826

Noormets A, Epron D, Domec JC, McNulty SG, Fox T, Sun G, King JS (2015) Effects of forest management on productivity and carbon sequestration: a review and hypothesis. Forest Ecol Manag 355:124-140

Pretzsch H, Biber P, Schütze G, Uhl E, Rötzer T (2014) Forest stand growth dynamics in Central Europe have accelerated since 1870. Nat Commun 5: 4967. https://doi.org/10.1038/ncomms5967

Schulze ED, Ciais P, Luyssaert S, Schrumpf M, Janssens IA, Thiruchittampalam B, Theloke J, Saurat M, Bringezu S, Lelieveld J, Lohila A, Rebmann C, Jung M, Bastviken D, Abril G, Grassi G, Leip A, Freibauer A, Kutsch W, Don A Nieschulze J, Börner A, Gash JH, Dolman AJ (2010) The European carbon balance. Part 4: integration of carbon and other trace-gas fluxes. Glob Chang Biol 16:1451-1469. https://doi.org/10.1111/j.1365-2486.2010.02215.x

Schulze ED, Frör O, Hessenmöller D (2016) Externe ökologische Folgen von Flächenstilllegungen im Wald. AFZ-Der Wald 15:24-26
Schulze ED, Luyssaert S, Ciais P, Freibauer A, Janssens IA, Soussana JF, Smith P, Grace J, Levin I, Thiruchittampalam B, Heimann M, Dolman AJ, Valentini R, Bousquet P, Peylin P, Peters W, Rödenbeck C, Etiope G, Vuichard N, Wattenbach M, Nabuurs GJ, Poussi Z, Nieschulze J, Gash JH, the CarboEurope Team (2009) Importance of methane and nitrous oxide for Europe's terrestrial greenhouse-gas balance. Nat Geosci 2:842-850

Schulze ED, Sierra CA, Egenolff V, Woerdehoff R, Irslinger R, Baldamus C, Stupak I, Spellmann $H$ (2020) The climate change mitigation effect of bioenergy from sustainably managed forests in Central Europe. GCB Bioenergy 12:186-197

Schulze ED, Wirth C, Heimann M (2000) Managing forests after Kyoto. Science 289:2058-2059

Thurner M, Beer C, Crowther T, Falster D, Manzoni S, Prokushkin A, Schulze ED (2019) Sapwood biomass carbon in northern boreal and temperate forests. Glob Ecol Biogeogr 28:640-660. https://doi.org/10.1111/geb.12883

Tomppo E, Schadauer K (2012) Harmonization of national forest inventories in Europe: advances under COST action E43. For Sci 58:191-200

Trumbore S, Czimczik C, Sierra CA, Muhr J, Xu X (2015) Non-structural carbon dynamics and allocation relate to growth rate and leaf habit in Californian oaks. Tree Physiol 35:1206-1222

UNFCCC-COP17 (2011) Conference of the Parties (COP17), Durban, 2011. 2/CMP.7 land use, land use change and forestry. https://unfccc.int/index.php/ process-and-meetings/conferences/past-conferences/durban-climate-changeconference-november-2011/cop-17. Accessed 15 Sep 2020

UNFCCC-COP21 (2015) Conference of the Parties (COP21) Paris, 2015. Adoption of the Paris Agreement. Proposal by the President. Paris Climate Change Conference - November 2015, COP 21, 21932 (December): 32. http://unfccc int/resource/docs/2015/cop21/eng/l09r01.pdf. Accessed 15 Sep 2020

Valentini R (2003) Fluxes of carbon, water and energy of European forests. Ecol stud vol. 163. Springer, Heidelberg, p 270

Vesala T, Suni T, Rannik Ü, Keronen P, Markkanen T, Sevanto S, Grönholm T, Smolander S, Kulmala M, Ilvesniemi H, Ojansuu R, Uotila A, Levula J, Mäkelä A, Pumpanen J, Kolari P, Kulmala L, Altimir N, Berninger F, Nikinmaa E, Hari P (2005) Effect of thinning on surface fluxes in a boreal forest. Global Biogeochem Cy 19:GB2001

von Carlowitz HC (1732) Sylvicultura oeconomica. Verlag Johann Friedrich Braun, Leipzig, p 248

Wilkinson M, Crow P, Eaton EL, Morison JIL (2016) Effects of management thinning on $\mathrm{CO}_{2}$ exchange by a plantation oak woodland in South-Eastern England. Biogeosciences 13(8):2367-2378

\section{Submit your manuscript to a SpringerOpen ${ }^{\circ}$ journal and benefit from:}

- Convenient online submission

- Rigorous peer review

- Open access: articles freely available online

High visibility within the field

- Retaining the copyright to your article

Submit your next manuscript at $>$ springeropen.com 